\title{
The Impact of Stackable Discounts on Retail Price Image
}

\author{
Dr. Shan Feng ${ }^{1}$ \& Dr. Jane Z. Cai ${ }^{2}$ \\ ${ }^{1}$ Assistant Professor in Marketing, William Paterson University, Wayne, NJ, USA \\ ${ }^{2}$ Senior Director of Partnership Programs, KnowledgeLink Education Group, Waltham, MA, USA \\ Correspondence: Dr. Shan Feng, Assistant Professor in Marketing, William Paterson University, 1600 Valley Rd., \\ Wayne, NJ, USA. Tel: 973-720-2766
}

Received: September 20, 2015

Accepted: October 15, 2015

Online Published: October 22, 2015

doi:10.5430/ijba.v6n6p26

URL: http://dx.doi.org/10.5430/ijba.v6n6p26

\begin{abstract}
Stackable discounts are gaining popularity in the marketplace but have received little research attention. This paper addresses this research gap by examining the impact of stackable discounts on retailers' price images. One experiment was conducted to compare the effects of stackable discounts with single discount on consumer price and value perceptions. The findings suggest that stackable discounts are superior to single discount in terms of creating a more favorable retail price image.
\end{abstract}

Keywords: stackable discounts, price image, price perception, value

\section{Introduction}

Retail image differentiates retailers from their competitors, although intangible, and has a long-lasting effect on consumers' purchase decisions. Consumers nowadays are constantly hunting for bargains, and the increased promotions in turn sensitize more consumers to retailers' price image (Van Heerde, Gijsbrechts, \& Pauwels, 2008). Many retailers (e.g., Saks Fifth Avenue) begin to offer deep discounts to boost sales and reduce operating costs through low inventory. A favorable price image of a retailer often involves the impression of low price (Schindler \& Kibarian, 2001), which in turn influences consumers' patronage decisions including whether they would shop at the store, how frequent they would shop there, and the amount of money they would spend in the store (Alba et al., 1994; Bell \& Lattin, 1998; Grewal et al., 1998; Sing et al., 2006; Srivastava \& Lurie, 2001; Urbany et al., 2000; Van Heerde, Gijsbrechts, \& Pauwels, 2008).

As stated by Levy et al. (2004), markdowns have become a "substantial and important aspect of today's retail landscape." In an attempt to attract consumer attention in such promotional clutter, many retailers have tried to vary the format of their discounts, among which stackable discounts becomes a prominent new approach. Once a promotional tool mostly adopted by off-price retailers (i.e., Loehmann's, outlets, etc.), stackable discounts now can be found within more upscale retailers such as department stores and specialty stores. A typical stackable discounts offer often comes on one coupon stating "xx\% off plus an additional $\mathrm{xx} \%$ off" or "save an additional $\mathrm{xx} \%$ off." Some stackable discounts are offered only when the total expenditure exceeds a certain amount, but many are valid within a time period without any constraint on usage. Moreover, stackable discounts can be more informative than a single discount in that the additional discounts could be framed to build relationship with consumers. For instance, Macy's once issued a stackable discount coupon which said "we love to share, so we're sharing with you: our employee discount, an extra $20 \%$ off" in red and " $10 \%$ off mattresses, furniture, area rugs, electronics and electronics" in black. The "extra 20\% off" shows goodwill from Macy's and may bring out benevolence from consumers as well.

A notable distinction of stackable discounts is that calculation is almost mandatory in the evaluation process. Researchers found that consumers often lack the capacity to accurately estimate price when computation is involved (Estelami, 2003; Kruger \& Vargas, 2008; Morwitz, Greenleaf, \& Johnson, 1998). Morwitz, Greenleaf, and Johnson (1998) showed that consumers often rely on heuristic processing when product price is presented in multiple pieces. As a result, the estimations of final price are often inaccurate and systematically distorted. This could be attributed to the reluctance of consumers to put in greater cognitive efforts to estimate final price (Kim \& Kramer, 2006). Kruger and Vargas (2008) offered further evidence to the distortion consumers experience about price. They investigated consumers' intuitions about percentage difference, and found that the perceived difference between two prices varied as a function of the target of comparison. That is, the subjective price difference between $\$ 1500$ and $\$ 1000$ is larger 
when $\$ 1500$ is described as 50\% more than $\$ 1000$ than when $\$ 1000$ is described as $33 \%$ less than $\$ 1500$.

Chen and Rao (2007) looked into the mechanism in which stackable discounts differ from a single discount (of equivalent economic value) when evaluating a single product price and proposed that consumers encounter "systematic computational error" with stackable discounts by adding up two percentage discounts, which results in larger perceived magnitude of the discount and higher purchase intention. However, it seems that retailers realize discounts could form lower price image for the store, as demonstrated by the big posters in the store window showing big discounts, or coupons that apply to multiple products. Indeed, researchers have found that consumers develop price image of a retailer through generalizing the prices of a small number of products, such as the most frequently purchased products or products that are most representative in their mind. By offering discounts on these products, retailers can effectively manipulate their price image. Yet no research has studied the effectiveness of stackable discounts in forming favorable price image for retailers. As it is easy to manipulate single discounts into stackable discounts, and by virtue of the richer context stackable discounts represents, retailers may enjoy stackable discounts as a better promotional tool than a single discount in some circumstances. Hence, our research intends to fill the gap in literature by examining the effect of stackable discounts on retailers' price image.

\section{Conceptual Framework}

\subsection{Processing of Stackable Discount}

As a powerful and effective strategic tool, pricing strategies used by retailers range from every day low prices (EDLP) to promotional or high-low prices (HILO). And some retailers use a combination of both, which is named a hybrid approach (Gauri, Trivedi, \& Grewal, 2008). Unlike EDLP, where strict control of cost and low profit margins is a constant focus in operations and management, the high and low prices uses promotions and occasional bargains to create transaction value, and have the advantage of being more flexible, selling with higher margins to the non-price sensitive consumers, and bring about higher margins in some less critical product categories (Cataluna et al., 2005). Many retailers that follow HILO pricing believe that temporary and aggressive price reductions help to maintain a low price image (Hoch et al., 1994). To further distinguish themselves from competitors and avoid consumer boredom, retailers often "frame" discounts in different ways to get consumer attention, such as percentage discounts, dollar discounts, free gifts, sweepstakes, and so on (Chen et al., 1998; Kim \& Kramer, 2006; Sinha \& Smith, 2000; Thaler, 1985).

Stackable discounts can be considered as a new variation of discounts used by retailers adopting HILO to impress consumers with a low price image. Prior research studying stackable discounts focuses on the errors in processing numbers. Indeed, consumers can easily make mistake on price when multiple numbers are involved. Morwitz, Greenleaf, and Johnson (1998) found that consumers often rely on heuristic processing to process multiple numbers, and the estimations of final price are often inaccurate and systematically distorted. Estelami (2003) further questioned the capability of consumers to calculate discounts and final prices of products accurately. He found that complex prices (such as prices in multiplicative form) require more evaluation effort from consumers than simple prices.

Echoing such concerns, Chen and Rao (2007) studied the price evaluation of a single product with stackable discounts, and found that consumers make "systematic computational errors" that lead to higher estimation of discount savings of stackable discounts compared to a single discount. That is, when facing an offer of "get $40 \%$ off plus an additional $20 \%$ off", a large proportion of consumers tend to add up the two numbers and conclude the actual discount level is $60 \%$ off, higher than the actual discount level of $52 \%$. To some extent, such "systematic computational error" is made consciously by consumers to avoid the complex computations required for more accurate estimations (Ashcraft, 1992; Johnson \& Payne, 1985). This heuristic is also more likely used when consumers lack of motivation or capacity to process information (Petty \& Cacioppo, 1986).

While Chen and Rao (2007) demonstrated that stackable discounts results in higher perception of savings on one promoted product, this paper looks at a related yet different research question: are stackable discounts more effective than single discounts to create a lower price image for retailers? For example, in designing a temporary discount for some product items or categories, would "get $40 \%$ off plus an additional $20 \%$ off" be more impressive than "get $52 \%$ off", even though the economic value is the same? In other words, would stackable discounts have any it remains a question whether stackable discounts would have any spill-over effect on retailers' overall price image, in addition to increasing sales of the promoted products? 


\subsection{Anchoring \& Adjustment}

As retailers generally carry large amount of products, it is often infeasible to advertise all prices to potential customers. The common practice is to advertise the low prices of a selected subset of products in the store, as grocery stores often do with the weekly fliers available at the entrance of stores, in the hope that consumers will generalize their impression of low prices to the entire store, thus creating a lower price image. Indeed, research has shown that while price is an important factor in making purchase decisions, consumers have difficulty remembering prices as exact numbers. Even seconds after they pick up a product from a retail shelf, only $47 \%-55 \%$ of consumers are able to recall its correct price (Dickson \& Sawyer, 1990; Le Boutillier, Le Boutillier, \& Neslin, 1994; Wakefield \& Inman, 1993). It happens partly because consumers don't pay as much attention to price information as marketers once believed (Dickson \& Sawyer, 1990). But it also lies in the fact that the cognitive capacity of consumers to encode, store, and retrieve prices is limited (Vanhuele, Laurent, \& Dreze, 2006). Instead of remembering prices as exact numbers, it is easier for consumers to convert prices into internal representation magnitude such as expensive or cheap (Monroe \& Lee, 1999). The relative position, rather than the actual price, is more important for consumers to judge the value of a product.

The formation of retail price image is a more complex task than the judgment of a single product. Not only does a consumer have to compare prices of a single product across stores, they also have to somehow be able to synthesize the price levels of thousands of products in the store. One shortcut used by consumers is to compare prices of a limited number of products, thus reducing the burden on the cognitive processing and making it more manageable. The selected few could either be the featured items advertised by the retailers, or the most frequently purchased items (Gourville \& Moon, 2004). Simester (1995) argues that by advertising its low prices for a sample of products, a low-cost retailer can credibly signal its costs for other products. If an inefficient high-cost store advertises a low price for one product, consumers will buy a large amount only of that product. Because the resulting loss dissuades inefficient stores from mimicking efficient ones, consumers can reliably infer that efficient stores charge low prices on unadvertised products as well.

Another way consumers form retailer price image is through price signaling. Research shows that consumers don't have an accurate sense of what the price should be for most of the items they buy, yet they rely on price cues to infer if they are getting a good price (Anderson \& Simester, 2003). In subtle and not-so-subtle ways, retailers can send signals to customers, telling them whether a given price is relatively high or low. For example, research has found that 99-ending prices communicate a low price image and create higher sales (Schindler \& Kibarian, 1996), compared to round-number prices. Stiving and Winer (1997) suggest that the right-hand digits of the price could cause the consumers to form perception about the retailers. They may infer that prices end in 99 because the product is on sale (Quigley \& Notarantonio, 1992); or that the price has been reduced (Schindler \& Kibarian, 1996); or that this is the lowest price available (Fortin et al., 2008). Another stream of research found that consumers take the frequency and magnitude of discounts as cues to infer the general price levels of competing stores (Alba et al., 1994). The higher the magnitude of discounts and the more frequent discounts are offered, the lower the average price perceptions are, which helps to build lower price image in the long run. Furthermore, Shin (2005) found that even vague appeals (such as "Big Sales") advertised by retailers are informative to infer a low price image.

In sum, consumers form price image for retailers to simplify their task of selecting places to shop. While the approaches of forming price image through sample prices and price signaling are not perfect, they help significantly reduce consumers' cognitive burden and can be gradually adjusted when new information comes in. As the focus of this paper, the authors are interested to see if different formats of discounts (single discount versus stackable discounts) does create a difference in consumers' perception of price image, thus providing new ideas to retailers on the management of retail image.

The literature on stackable discounts suggests that stackable discounts are perceived as a more favorable promotion than a single discount due to the systematic computational error involved in the computation (Chen \& Rao, 2007). When consumers only have the discount(s) information as a signal to infer a retailer's price image, the higher perceived magnitude of stackable discounts would likely lead to lower price image for the retailer. Therefore, it is proposed that

Hypothesis: Consumers perceive the price image of a retailer using stackable discounts to be lower than that of a retailer using a single discount of equivalent economic value. 


\section{Experiment}

\subsection{Experimental Design}

The main experimental variables of interest in this study are discount format (single vs. stackable discounts) and discount presentation (category-wise discount vs. product-specific discount). A careful study of offline and online discount promotions showed that retailers often present discounts in two ways. One is to present a category-wise or store-wise discount that applies to all items in one category or one store, where exclusions may apply. Such discount promotions can easily be delivered through promotional coupons or retailer websites. The other way is to present product-specific discounts for all products on sale. Each product can have a different level of discount. The product information, price, and discount information are summarized in a product matrix or a product list. As Chen and Rao (2007) have demonstrated that stackable discounts associated with a single product increases the perception of savings and purchase intention, we suspect that the repeated presentation of stackable discounts with individual products would reinforce the impression of stackable discounts and fortify the proposed stackable discounts effect in reducing price image.

\subsection{Procedure}

Sixty-three U.S. undergraduate students (55.6\% male; average age: 21$)$ from an introductory marketing class participated for extra course credit in this online experiment. The introductory instructions asked subjects to look at a screenshot of a retailer website and imagine they were considering purchasing the product in a real shopping experience. Then each subjects was randomly assigned to one of four conditions (2: discount formats $\mathrm{x} 2$ : presentation order). In each condition, a subject viewed both sections of store promotions, each followed by a set of questions on the same dependent variables, but in different orders. Discount format was carefully distributed across sections so that each subject only sees the single discount(s) and stackable discounts once. One section shows the category-wise discount as a webpage demonstrating discount information (either single or stackable discounts) for a product category (i.e., shirts) in the center of the page, with three shirts listed in a row at the bottom. No price or brand information was revealed. The other section shows the product-specific discount as a product information webpage consisting 9 cameras listed in a product matrix, each product associated with a brand name, a short product description, price, and discount information (either single or stackable discounts). Figure 1 shows the promotion page stimuli. The discount format was a between-subject factor and the promotion page format was a within-subject factor. By varying the promoted products in the webpages, we are trying to create the impression that two retailers are evaluated separately.

The dependent variable of interest is the retailer's perceived price image, which is a 4-item scale adapted from Cox and Cox's (1990) measures of retail price image (e.g., this retailer would probably offer low/high overall prices). We also included the measures of deal evaluations, perception of savings for the promotion, transaction value, purchase intention, and search intention, to further explore the difference between stackable discounts and a single discount. Based on Chen and Rao's (2007) research, we expect that deal evaluations, perception of savings, and purchase intentions will be higher for stackable discounts than a single discount.

Transaction value is defined as "the perception of psychological satisfaction or pleasure obtained from taking advantage of the financial terms of the price deal" (Grewal et al., 1998). As a single discount has the advantage of being simple and straightforward, it may strike the emotional reactions of consumers more directly. In contrast, stackable discounts demands more processing from the consumers to figure out the actual discount level, which may hinder the sensitivity to pleasure. Hence, we predicted transaction value to be higher with a single discount than with stackable discounts.

Search intention is similar to the construct of "purchase deferral" used in Hamilton and Chernev (2010), which measures the likelihood a consumer chooses to look for a better price elsewhere rather than to buy at the current price. It should correlate positively with retailer price image and share the same direction of prediction across discount formats. All measures are on a 7-point scale.

Finally subjects reported their age, gender, and past experience with online shopping. These factors were used as co-variants but had no impact on the data analysis. The subjects were also asked to guess the purpose of this study. No one made correct answers. 


\subsection{Results}

Data analysis was conducted separately on the two versions of promotion pages. The camera version (scattered discount) yielded no significant result across all dependent variables. So the following focuses on the findings based on the shirt version (focal discount).

Manipulation check of discount format was obtained by asking subjects to choose among three discounts the one they saw in the previous webpage: $65 \%$ off, $50 \%$ off plus an additional $30 \%$ off, and $50 \%$ off. Most subjects ( $83 \%$ ) chose the correct one. The ones selecting the wrong answer were dropped from further analysis, resulting in 52 subjects.

A 2 (discount formats) x 2 (presentation orders: shirt version was presented first or second) ANOVA was first conducted on the dependent variables. No order effect was identified. Hence, the data was collapsed across presentation orders, and a one-way ANOVA was conducted on the dependent variables. Consistent with our hypothesis, the perception of retail image is lower with stackable discounts than with a single discount $\left(\mathrm{M}_{\text {stackable }}=\right.$ 3.27 vs. $\left.\mathrm{M}_{\text {single }}=4.06 ; \mathrm{F}(1,50)=5.06, \mathrm{p}<0.05\right)$. The other dependent variables showed patterns consistent with our predictions but none was significant (Tables $1 \& 2$ ).

Table 1. Effects of discount format on consumers' perception of retailer price image

\begin{tabular}{lllll}
\hline \multirow{1}{*}{ DVs } & \multicolumn{2}{c}{ Mean Values } & F-value & p-value \\
\cline { 2 - 4 } & Single Discount & $\begin{array}{c}\text { Stackable } \\
\text { Discounts }\end{array}$ & \\
\hline Price Image & 4.06 & 3.27 & 5.06 & $>0.05$ \\
\hline Deal Evaluation & 5.28 & 5.64 & 1.08 & $>0.10$ \\
\hline $\begin{array}{l}\text { Perception of } \\
\text { Savings }\end{array}$ & 4.83 & 5.07 & 1.27 & $>0.10$ \\
\hline Purchase Intention & 4.74 & 5.08 & 0.56 & $>0.10$ \\
\hline Search Intention & 4.56 & 4.03 & 1.41 & $>0.10$ \\
\hline Transaction Value & 5.63 & 5.32 & 0.77 & \\
\hline
\end{tabular}


Table 2. Effects of discount format on consumers' perception of other dependent variables

\begin{tabular}{|c|c|c|c|c|c|c|c|}
\hline & & \multicolumn{3}{|c|}{ High price image } & \multicolumn{3}{|c|}{ Low price image } \\
\hline & & Single & Double & Justification & Single & Double & Justification \\
\hline & manipulation 1 & 5.67 & & & 3.49 & & \\
\hline & manipulation 2 & 5.13 & & & 3.18 & & \\
\hline & manipulation 3 & 5.41 & & & 3.36 & & \\
\hline 2 & Happiness & 3.77 & 3.85 & 3.77 & 3.8 & 3.67 & 4.08 \\
\hline 3 & Promotion 1 & 4.62 & 4.46 & 4.62 & 4.87 & 4.92 & 5.33 \\
\hline 4 & Promotion 2 & 5.31 & 5.23 & 4.85 & 5.13 & 5.17 & 5.25 \\
\hline 5 & Discount 1 & 4.46 & 4.92 & 4.15 & 4.4 & 4.33 & 4.83 \\
\hline 6 & Discount 2 & 4.69 & 5.31 & 3.69 & 5.27 & 4.5 & 5 \\
\hline 7 & Discount 3 & 4.92 & 5.08 & 4.38 & 4.93 & 4.58 & 5.08 \\
\hline 8 & $\begin{array}{l}\text { Transaction } \\
\text { value } 1\end{array}$ & 5.69 & 5.15 & 5.23 & 5.87 & 5.17 & 5.42 \\
\hline 9 & $\begin{array}{l}\text { Transaction } \\
\text { Value } 2\end{array}$ & 5.62 & 5.77 & 5.15 & 5.73 & 5.5 & 5.67 \\
\hline 10 & $\begin{array}{l}\text { Transaction } \\
\text { Value } 3\end{array}$ & 4.85 & 5.85 & 5.31 & 6 & 5 & 4.92 \\
\hline 11 & Price image 1 & 5 & 5.08 & 5 & 3.33 & 4.08 & 4 \\
\hline 12 & Price Image 2 & 5.54 & 5.38 & 5 & 3.4 & 3.75 & 3.58 \\
\hline 13 & Price Image 3 & 4.15 & 4.85 & 4.15 & 5.33 & 5 & 5 \\
\hline 14 & Price Image 4 & 3.92 & 4.85 & 3.69 & 4.93 & 5 & 5.33 \\
\hline 15 & $\begin{array}{l}\text { Purchase } \\
\text { intention } 1\end{array}$ & 4.77 & 4.46 & 4.77 & 4.4 & 4.67 & 5.33 \\
\hline 16 & $\begin{array}{l}\text { Purchase } \\
\text { intention } 2\end{array}$ & 4.46 & 5.23 & 4.77 & 5.13 & 4.5 & 5.17 \\
\hline 17 & Search 1 & 6.15 & 6.38 & 5.15 & 4.93 & 5.17 & 5.17 \\
\hline 18 & Search 2 & 6.69 & 6.31 & 5.31 & 6 & 5.42 & 6.17 \\
\hline 19 & Search 3 & 6.54 & 6.46 & 5.61 & 5.13 & 5.5 & 5.75 \\
\hline 20 & Relationship 1 & 5.31 & 5.38 & 4.92 & 4.8 & 5 & 5.16 \\
\hline 21 & Relationship 2 & 5.54 & 5.38 & 5.15 & 5.07 & 5.25 & 5.25 \\
\hline 22 & Relationship 3 & 5.31 & 5.31 & 5.54 & 5.67 & 5.25 & 5.42 \\
\hline & Diff & 0.81 & 0.19 & 1.05 & -.92 & -1.15 & -1.09 \\
\hline
\end{tabular}

The results suggested that high-end retailers should offer overlapping products in their stores to encourage price comparison, signal price fairness and foster a more favorable price image.

The importance of price image lies in the fact that once formed, it may be hard to change (Hoch \& Deighton, 1989). Conflict between prior beliefs and a data-based cue will prompt deeper processing, resulting in accurate perception of the value offered by each store (Alba et al., 1994).

Researchers have noticed that different stores with varied characteristics often choose different price strategies to make sound value propositions to their customers (Gauri, Trivedi, \& Grewal, 2008). On the other hand, consumers 
may associate certain price strategies with retailers' service levels (Iyer 1998; Leszczyc, Sinha, \& Sahgal, 2004), and hence interpret the same price tactics with different meanings if the senders are different types of retailers.

Similarly, stackable discounts are often used by off-price retailers and outlet mall merchants, which may condition consumers to associate stackable discounts with low price image even when high-end retailers adopt this promotion format. Hence, we propose that,

\section{Conclusion}

We argue retailers could use stackable discounts in two contexts in their favor. One is to use stackable discounts in a coupon or on the retailer website to signify the promotion. The other is to use stackable discounts in the product presentation page of a website, emphasizing bigger discounts for each products and hence lowering the overall price image of the retailer. The findings from the experiment showed support for the first context, but not for the latter. It could be due to the dilution effect by information overflow. When product information, price, and discounts are presented at the same time, especially in a product matrix, consumers face a flood of information and lose their focus on the discount promotions. Hence, stackable discounts do not differ much from single discounts in impressing consumers and more succinct presentation of discount information (i.e., single discount) may be more helpful to consumers. However, we do find that retailers can take advantage of stackable discounts in some occasions to create a lower price image for their stores. By simply presenting category-wise or store-wise promotions in stackable discounts format rather than a single discount, retailer can enjoy a lower price image at minimal cost.

In addition to creating a more favorable price image to retailers, stackable discounts are at least as effective in driving perception of savings and motivating consumers to purchase the products on sale (see Table 1). Hence, stackable discounts should be considered as an important promotional tool. Especially in conditions where promotional offers are highlighted, stackable discounts have the potential to attract more favorable responses and build more competitive image for the retailer.

\section{Future Research}

This research represents the first attempt to delineate the linkage between stackable discounts and retailers' price image. Although the findings reported in this paper is encouraging, there are many boundary conditions that need to be addressed. First, we used a hypothetical online retailer in the experimental study. Would the existing retail image of a retailer interact with the stackable discounts effect? Especially, would high-end retailers and low-end retailers benefit in the same way by using stackable discounts? Retail image consists of two basic elements: price image and quality image. While stackable discounts are associated with a lower price image, would they create a lower quality image for the retailers? If that is the case, then high-end retailers should be cautious in evaluating the tradeoff between lower price image and reduced quality image created by using stackable discounts.

Secondly, stackable discounts can be designed into loyalty programs or special promotion programs. For example, Kmart offers extra $15 \%$ discount for senior citizens. Many loyalty programs offer consumers extra discounts based on accumulated points or sales. Little is known how these targeted offers could impact on the retailer's price image.

Thirdly, this paper only considered stackable discounts that are composed of both percentage discounts. Much discussion has been devoted to the differential effects of percentage-off versus dollar-off discounts (e.g., Chen, Monroe, and Lou, 1998). In future research, the effects of different formats of stackable discounts should be considered and explored.

\section{References}

Alba, J. W., Broniarczyk, S. M., Shimp, T. A., \& Urbany, J. E. (1994). The influence of prior Beliefs, frequency cues, and magnitude cues on ponsumers' Perceptions of comparative price data. Journal of Consumer Research, 21 (September), 219-235. http://dx.doi.org/10.1086/209394

Anderson, E. T., \& Simester, D. I. (2003). Effects of $\$ 9$ price endings on retail sales: Evidence from field experiments. Quantitative marketing and Economics, 1(1), 93-110. http://dx.doi.org/10.1023/A:1023581927405

Ashcraft, M. H. (1992). Cognitive arithmetic: a review of data and theory. Cognition, 44, 75-106. http://dx.doi.org/10.1016/0010-0277(92)90051-I

Bell, D. R., \& Lattin, J. M. (1998). Shopping behavior and consumer preference for store price format: why "large basket" shoppers prefer EDLP. Marketing Science, 17 (March), 66-88. http://dx.doi.org/10.1287/mksc.17.1.66

Chen, H., \& Rao, A. R. (2007). When two plus two is not equal to four: errors in processing multiple percentage changes. Journal of Consumer Research, 34 (October), 327-340. http://dx.doi.org/10.1086/518531 
Chen, S., Monroe, K. B., \& Lou, Y. (1998). The effects of framing price promotion messages on consumers' perceptions and purchase intentions. Journal of Retailing, 74 (3), 353-372. http://dx.doi.org/10.1016/S0022-4359(99)80100-6

Cox, A. D., \& Cox, D. (1990). Competing on price: the role of retail price advertisements in shaping store-price image. Journal of Retailing, 66 (4), 428-445.

Dickson, P. R., \& Sawyer, A. G. (1990). The price knowledge and search of supermarket shoppers. Journal of Marketing, 54 (3), 42-53. http://dx.doi.org/10.2307/1251815

Estelami, H. (2003). The effect of price presentation tactics on consumer evaluation effort of multi-dimensional prices. Journal of Marketing Theory and Practices, 11 (2), 1-15.

Fortin, D., Cleland, S., \& Jenkins, A. (2008). Effects of advertised pricing on brand image for an on-line retailer. Proceedings of the 2008 Conference of the American Academy of Advertising, 263-275.

Gauri, D. K., Trivedi, M., \& Grewal, D. (2008). Understanding the determinants of retail strategy: an empirical analysis. Journal of Retailing, 84 (3), 256-267. http://dx.doi.org/10.1016/j.jretai.2008.06.004

Gourville, J. T., \& Moon, Y. (2004). Managing price expectations through product overlap. Journal of Retailing, 80(1), 23-35. http://dx.doi.org/10.1016/j.jretai.2004.01.002

Grewal, D., Monroe, K. B., \& Krishnan, R. (1998). The effects of price comparison advertising on buyers' perceptions of acquisition value and transaction value. Journal of Marketing, 62 (April), 46-59. http://dx.doi.org/10.2307/1252160

Hamilton, R., \& Chernev, A. (2010). The impact of product line extensions and consumer goals on the formation of price image. Journal of Marketing Research, 47 (1), 51-62. http://dx.doi.org/10.1509/jmkr.47.1.51

Hoch, S. J. \& Deighton, J. (1989). Managing what consumers learn from experience. Journal of Marketing, 53 (April), 1-20. http://dx.doi.org/10.2307/1251410

Hoch, S. J., Dreze, X., \& Purk, M. E. (1994). EDLP, Hi-Lo, and margin arithmetic. Journal of Marketing, 58 (October), 16-29. http://dx.doi.org/10.2307/1251913

Iyer, G. (1998). Coordinating channels under price and nonprice competition. Marketing Science, 17(4), 338-355. http://dx.doi.org/10.1287/mksc.17.4.338

Johnson, E. J., \& Payne, J. W. (1985). Effort and accuracy in choice. Management Science, 31 (4), 395-414. http://dx.doi.org/10.1287/mnsc.31.4.395

Kim, H. M., \& Kramer, T. (2006). "Pay 80\%" versus "get 20\% off": the effect of novel discount presentation on consumers' deal perceptions. Marketing Letters, 17, 311-321. http://dx.doi.org/10.1007/s11002-006-9309-7

Kruger, J., \& Vargas, P. (2008). Consumer confusion of percent differences. Journal of Consumer Psychology, 18 (1), 46-61. http://dx.doi.org/10.1016/j.jcps.2007.10.009

Le Boutillier, J., Le Boutillier, S. S., \& Neslin, S. A. (1994). A replication and extension of the Dickson and Sawyer price-awareness study. Marketing Letters, 5(1), 31-42. http://dx.doi.org/10.1007/BF00993956

Leszczyc, P. T. P., Sinha, A., \& Sahgal, A. (2004). The effect of multi-purpose shopping on pricing and location strategy for grocery stores. Journal of Retailing, 80(2), 85-99. http://dx.doi.org/10.1016/j.jretai.2004.04.006

Levy, M., Grewal, D., Kopalle, P. K., \& Hess, J. D. (2004). Emerging trends in retail pricing practice: implications for research. Journal of Retailing, 13 (21), 13-21. http://dx.doi.org/10.1016/j.jretai.2004.08.003

Monroe, K. B., \& Lee, A. Y. (1999). Remembering versus knowing: Issues in buyers' processing of price information. Journal of the Academy of Marketing Science, 27(2), 207-225. http://dx.doi.org/10.1177/0092070399272006

Morwitz, V. G., Greenleaf, E. A., \& Johnson, E. J. (1998). Divide and prosper: consumers' reaction to partitioned prices. Journal of Marketing Research, 35 (November), 453-463. http://dx.doi.org/10.2307/3152164

Petty, R. E., \& Cacioppo, J. T. (1986). Communication and persuasion: central and peripheral routes to attitude change. New York: Springer-Verlag. http://dx.doi.org/10.1007/978-1-4612-4964-1

Quigley, C. J., \& Notarantonio, E. M. (1992). An exploratory investigation of perceptions of odd and even pricing. in Proceedings of the 1992 Academy of Marketing Science (AMS) Annual Conference, 306-309. 
Schindler, R. M., \& Kibarian, T. M. (1996). "Increased Consumer Sales Response through Use of 99-Ending Prices," Journal of Retailing, 72 (2), 187-199. http://dx.doi.org/10.1016/S0022-4359(96)90013-5

Schindler, R. M., \& Kibarian, T. M. (2001). Image communicated by the use of 99 endings in advertised prices. Journal of Advertising, 30 (4), 95-99. http://dx.doi.org/10.1080/00913367.2001.10673654

Shin, J (2005). The role of selling costs in signaling price image. Journal of Marketing Research, 42 (August), 302-312. http://dx.doi.org/10.1509/jmkr.2005.42.3.302

Simester, D. (1995). Signalling price image using advertised prices. Marketing Science, 14(2), 166-188. http://dx.doi.org/10.1287/mksc.14.2.166

Sing, V., Hansen, K., \& Blattberg, R. (2006). Market entry and consumer behavior: an investigation of a Wal-Mart supercenter. Marketing Science, 25 (September-October), 457-476. http://dx.doi.org/10.1287/mksc.1050.0176

Sinha, I., \& Smith, M. F. (2000). Consumers' perceptions of promotional framing of price. Psychology \& Marketing, 17 (3), 257-275. http://dx.doi.org/10.1002/(SICI)1520-6793(200003)17:3<257::AID-MAR4>3.0.CO;2-P

Srivastava, J., \& Lurie, N. (2001). A consumer perspective on price-matching refund policies: effect on price perceptions and search behavior. Journal of Consumer Research, 28 (September), 296-307. http://dx.doi.org/10.1086/322904

Stiving, M., \& Winer, R. S. (1997). An empirical analysis of price endings using scanner data. Journal of Consumer Research, 24 (6), 57-67. http://dx.doi.org/10.1086/209493

Thaler, R. (1985). Mental accounting and consumer choice. Marketing Science, 4 (3), 199-214. http://dx.doi.org/10.1287/mksc.4.3.199

Urbany, J. E., Dickson, P. R., \& Sawyer, A. G. (2000). Insights into cross- and within-store price search: retailer $\begin{array}{llllllll}\text { estimates vs. } \quad \text { consumer self-reports. Journal of Retailing, } 76 & \text { (2), 258. }\end{array}$ http://dx.doi.org/10.1016/S0022-4359(00)00025-7

Van Heerde, H. J., Gijsbrechts, E., \& Pauwels, K. (2008). Winners and losers in a major price war. Journal of Marketing Research, 45 (October), 499-518. http://dx.doi.org/10.1509/jmkr.45.5.499

Vanhuele, M., Laurent, G., \& Dreze, X. (2006). Consumers' immediate memory for prices. Journal of Consumer Research, 33(2), 163-172. http://dx.doi.org/10.1086/506297

Wakefield, K. L., \& Inman, J. J. (1993). Who are the price vigilantes? An investigation of differentiating characteristics influencing price information processing. Journal of Retailing, 69(2), 216-233. http://dx.doi.org/10.1016/0022-4359(93)90004-3 
Appendix

Promotion stimuli used in the experimental study

a. Focal discount design (stackable discounts)

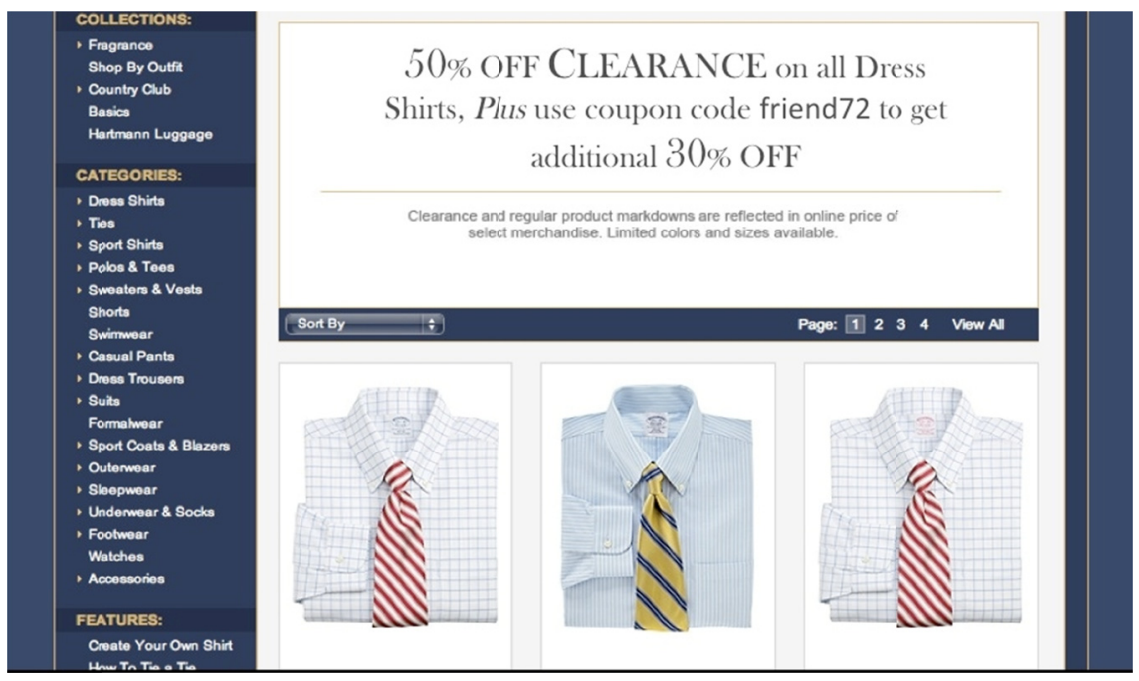

b. Scattered discount design (stackable discounts)

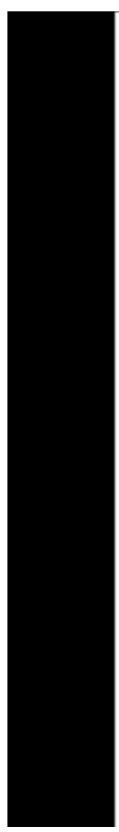

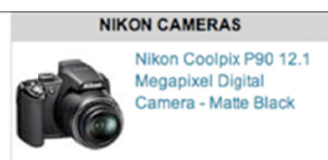

Was $\$ 399.95$
Save $10 \%$ plus an extra $10 \%$ off

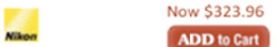

SONY CAMERAS

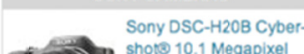

17.

(Q)) Digital Camera - Black

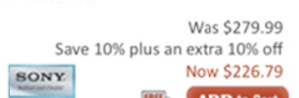

SONY Now $\$ 226.79$

$$
\text { ADD to Cart }
$$

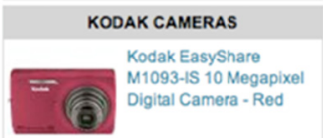

\begin{tabular}{|r|r|} 
& Was $\$ 199.99$ \\
Save 40\% plus an extra $10 \%$ off \\
Kodak & Now $\$ 107.99$ \\
\hline ADD to Cart
\end{tabular}
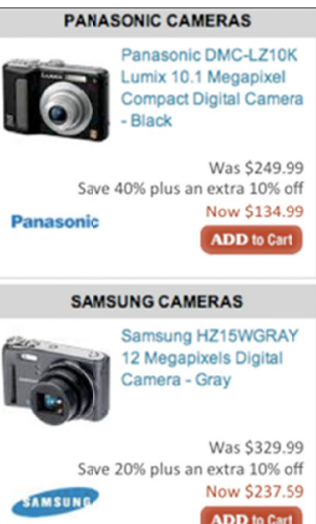

ADD to Cart

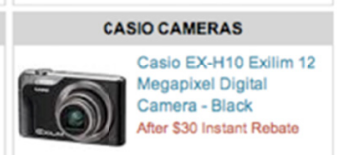

Was $\$ 279.99$ extra $10 \%$ off \begin{tabular}{ll|ll} 
CASIO. & Now $\$ 201.59$ & & Panasonic \\
ADD to Cart & Now $\$ 129.59$ \\
& ADD to Cart
\end{tabular}

\begin{tabular}{ll|ll} 
CASIC. & Now $\$ 201.59$ & Panasonic & Now $\$ 129.59$ \\
& ADD to Cart & ADD to Cart
\end{tabular}

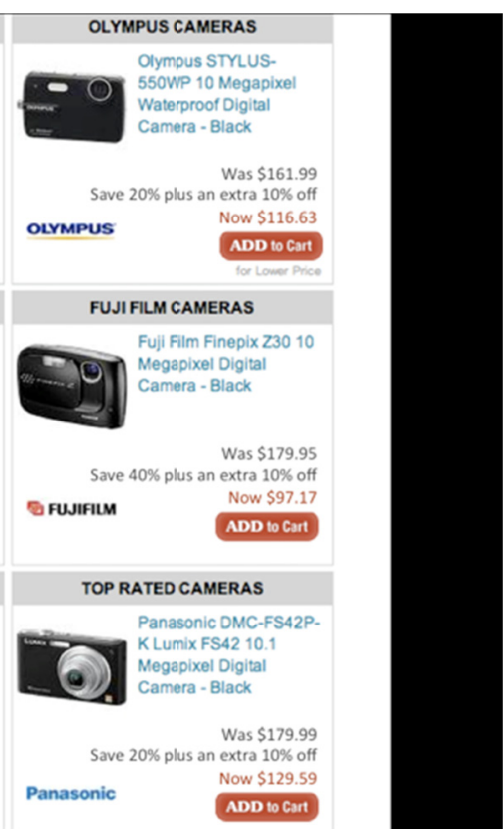

